\title{
Loan Growth and Bank Performance: A Panel ARDL Approach
}

Jhabindra Pokharel *

\section{Abstract}

This paper analyzed the effect of loan growth in three performance aspects, profitability, stock return and credit risk of Nepalese commercial banks applying the panel autoregressive distributed lag (ARDL) approach. To avoid the effect of the merger on loan growth 8 banks which have not merged with or acquired other institutions are taken as sample and 8-year data from each sample bank from 2012- 2019 has been sued in the study. The result showed that none of the three performance indicators is affected by the loan growth in the long-run. It is also found that the credit risk of banks does not change with the change in loan growth in the short-run as well. This indicates that banks are not aggressive in their lending. However, profitability and stock return are affected positively by the loan growth in the short-run. The findings from this study suggest to the investors in the stock market to choose the stock of bank with higher loan growth.

Keywords: loan growth, stock return, credit risk, non-performing loans, bank performance

\section{Background}

The performance of the main investment portfolio of depository financial institutions, loan portfolio, depends on various factors like the general economic condition, industry-specific slackness or peak, government regulation, catastrophic events, funding sources, cost of fund, loan interest rate, competition among institutions and more other factors (Rose \& Hudgins, 2008). Similarly, the performance of a bank depends on how its loan portfolio performs and how effectively the bank has scanned its borrowers' creditworthiness. The non-performance of loan results in various types of risks like reduced profitability due to high bad debts; liquidity risk due to the mismatch in cash inflows and outflows or mismatch between maturities of assets and liabilities; and interest rate risk due to change in interest rate risk. This also affects the value maximization objective of banks. Therefore, the outsiders and the stockholders also look at the loan portfolio and its riskiness while making investment decisions.

In an expansionary economy, bank credit also expands and the riskiness of loan portfolios also increases. The credit boom generally ends with poor economic performance and sometimes the crash. More credit-intensive expansions tend to be followed by deeper recessions (in

* Lecturer, Shanker Dev Campus, Tribhuvan University

E-mail: Thabindra.pokharel@sdc.tu.edu.np 
financial crises or otherwise) and slower recoveries and such financial recessions are costlier (Jorda et al., 2013). The expansion of credit is necessary for the expansion of the economy or the development of an economy but the fast expansion of credit may result in an accident like loan supply shock and liquidity crisis. The boom in credit to the household sector and the enterprises that are not financial are important in explaining financial crashes or instability in the financial system (Anundesen et al., 2016). Baker (2008) argued that the subprime credit crisis that started in 2007 was the consequence of lower interest rates of the Federal US, which encouraged the banks, marketing risky mortgage products aggressively and increasing the lending to subprime customers at reduced risk premiums. This resulted in the default of more loans and a liquidity crisis occurred. This was the effect of fast loan growth before the crisis period. However, the post-crisis loan growth rates were lower than pre-crisis loan growth rates (Cyree, et al., 2016). This clearly shows that fast loan growth results in poor performance of banks.

Bank's loan portfolios contain potentially useful information about local economic conditions as commercial banks are the main financial institutions whose activities directly reflect the true economic conditions. Information in loan portfolios aggregated to the state level is associated with current and future changes in statewide economic conditions (Khan \& Ozel, 2016). Furthermore, the provision for loan and lease losses contains information incremental to leading indicators of economic activity and recessions. Loan portfolio information also helps to improve predictions of economic conditions.

A bank with a loose credit policy may have to bear more default loans and more loan loss provisions. These types of risk (default risk) also affect the liquidity position and profitability of the bank. The loan growth is also an indicator of riskiness and future performance of the bank. Foos et al. (2010) also found that loan growth leads to an increase in loan loss provisions, to a decrease in relative interest income, and lower capital ratios. Further, loan growth also has a negative impact on the risk-adjusted interest income. These results suggest that loan growth represents an important driver of the riskiness of banks. When banks aggressively provide loans to sub-prime customers whose creditworthiness score is low, more loans may default and the bank has to increase the loan loss provision, which results in lower profit, lower ROE and lower ROA. In such cases, the stock of the bank also underperforms the market and the value of the bank declines (Fahlenbrach, et al., 2018). This also indicates that fast loan growth results in poor stock prices.

If a credit manager has an incentive to lend more to show his/her performance to the top management, they may grant loans to relatively risky borrowers. When there is an incentive to lend, lenders generally lend at a lower interest rate to increase the volume of lending. This hypothesis is commonly known as agency theory as there is an incentive to take more risk to satisfy the principal (top management or shareholders) by agent (credit managers). Rajan (1994) focuses that the main reason why banks lower their credit standards is the implication of short-term incentive of bank managers to boost up the bank's profitability and return to shareholders by booking the fees from loans. While focusing on current profitability, credit 
managers are ignoring the future risk of possible default. Customers' bargain power and the incentive to lend result in lower interest spread. Thus, a credit boom is accompanied by a period of low spread and which is followed by poor economic performance and the high spread (Bordalo et al., 2018). This indicates that banks can lend with low spread in a rapid loan growth period but increase spread when lending volume decreases.

If future catastrophe can be predicted with the loan growth, various participants in the economy can take precautions to avoid the loss, reduce the magnitude of loss or shorten the period of recession. By realizing this fact, it is considered to be worthwhile to study whether the loan growth or the pace of lending activities can predict the future performance of banks in Nepal. Therefore, this article examines the impact of loan growth on other performance measures namely the stock return, accounting return and credit risk of banks in Nepal.

\section{Literature Review}

Vogiazas and Alexiou (2015) suggest that key variables - such as solvency, non-performing loans and cost-efficiency play an instrumental role in explaining banks' return. Glen and Mondragon-Velez (2011) found higher loan loss provisions are associated with private sector leverage, poor loan portfolio quality, and lack of banking system penetration and capitalization. Growth in loan portfolios had a positive effect on the financial performance of commercial banks and the quality of bank assets had a positive effect on the financial performance of commercial banks in Kenya (Thiongo et al., 2016). Similarly, Foos et al. (2010) conclude that loan growth leads to an increase in loan loss provisions during the subsequent three years, to a decrease in relative interest income, and to lower capital ratios. Further analyses showed that loan growth also has a negative impact on the risk-adjusted interest income. These results suggest that loan growth represents an important driver of the riskiness of banks.

Amador and Gomez (2013) studied the relationship between abnormal loan growth and banks' risk-taking behavior, using data from a rich panel of Colombian financial institutions. The result showed that abnormal credit growth during a prolonged period leads to an increase in banks' riskiness, supported by a reduction of solvency and an increase in the ratio of non-performing loans to total loans. The study also showed that abnormal credit growth played a fundamental role in the bank-failure process during the late 1990s financial crisis in Colombia. Chavan and Gambacorta (2016) indicated that an increase in abnormal loan growth is associated with an increase in NPL in the long run with the response being higher during expansionary phases. Furthermore, there is a pro-cyclical risk-taking response to credit growth in the case of both public and private banks with private banks being more reactive to changes in interest rate and business cycle conditions. Soedarmono (2017) had found that higher loan growth increases bank systematic risk but the result is countryspecific. In countries with higher credit information index and better private credit bureaus, the impact of lagged value of abnormal loan growth is reversed.

Liu et al. (1997) argue that loan loss provisions are positively associated with bank stock returns and future cash flows. But these positive valuation implications are obtained only for 
loan loss provisions for low regulatory capital banks. Ibrahim (2006) verified that bank loans react positively to the increase in stock prices but there seems to be no influence from bank loans to stock prices. However, the study of Kim and Moreno (1994) showed a time-varying effect of bank loans on stock return in Japan. The study found that before the mid-1980s the relationship between stock prices and bank lending was weak but subsequently strengthened considerably. This coincided with a change in the regulatory environment that encouraged banking institutions to pay more attention to their capital positions. The information that loan growth conveys depends on the feature of the bank, the loan and the macroeconomic state. If market reaction conveys meaningful information about a bank's value, then loan portfolio growth should predict future performance measures of the bank, especially the future nonperforming loans (Zemel, 2018). Furthermore, Zemel (2018) also found a positive stock market reaction to the loan portfolio growth for high-income banks and a negative reaction to the loan portfolio growth for low-income banks.

\section{Methodology Variables}

This study analyzes the impact of loan growth on the performance of banks. Three measures of performance are taken into consideration. Accounting performance is measured by return on assets (ROA), return on equity (ROE) and interest spread (SPREAD). Market performance is measured by the stock return of the respective bank. Stock returns within the same year $(\mathrm{SR})$ and one-year back $\left(\mathrm{SR}_{\mathrm{t}-1}\right)$ are used separately in the models. The third indicator that is assumed to be affected by loan growth is credit risk. Credit risk for this study is represented by non-performing loans (NPL) and risk-weighted exposure for credit risk (RWA). The independent variable is loan growth. Loan growth within the same year (LG) and one year back have $\left(\mathrm{LG}_{\mathrm{t}-1}\right)$ been included as two independent variables.

\section{Sampling and Data}

From 27 commercial banks, only eight banks have been selected as samples for this study. Since government banks are not fully profit-oriented banks, three banks involving government ownership have been excluded from the study. During the past decade, many of the commercial banks in Nepal have gone through mergers and acquisitions. To remove the effect of a merger on loan growth, banks that have gone through major mergers and acquisitions during the sample period have been excluded from the sample. Only 8 banks remained that have not merged or acquired any other institutions. Therefore, these banks have been taken as samples to study the impact of organic loan growth on performance.

The sampling period covers from 2012 to 2019 for each sample bank. Annual time-series data for each of the sample banks has been used. Data for stock price, ROA, ROE, spread riskweighted exposure for credit risk, NPL, loan volume and total assets have been taken from various annual reports of respective banks.

\section{Econometric Model}

The basic model for the study is 
$\left.Y_{i t}=f\left[L_{i, t^{\prime}} L G_{i, t-1}\right)\right]$

where $y_{i t}$ denotes the independent variables, $L_{i, t}$ is the growth rate in loan provided by $i^{\text {th }}$ bank in year $t$, and $L G_{i, t-1}$ is one-year lagged loan growth rate of $i^{\text {th }}$ bank. This study applies the autoregressive distributed lag (ARDL) model for estimation. The estimation of ARDL requires that the variables should be stationary at level or at first difference. For this, unit root test developed by Levin et al. (2002) have been applied.

$\Delta \mathrm{y}_{\mathrm{i}, \mathrm{t}}=\gamma_{0 \mathrm{i}}+\rho \mathrm{y}_{\mathrm{it}-1}+t=0 p \mathrm{i} \gamma_{1 \mathrm{i}} \Delta \mathrm{y}_{\mathrm{i}, \mathrm{t}-\mathrm{j}}+\mu_{\mathrm{i}, \mathrm{t}} \ldots \ldots \ldots[2]$

where $\gamma$ is the constant term, which is supposed to differ across cross sectional entities while $\rho$ is the identical autoregressive coefficient, $\gamma_{i}$ denotes the lag order, $\mu_{i, t}$ is the disturbance term.

The estimation method used in this paper, the generalized ARDL (p, q, q, ... q) model is specified as

$\mathrm{y}_{\mathrm{it}}=j=1 p \delta_{\mathrm{ij}} \mathrm{y}_{\mathrm{i}, t-\mathrm{j}}+j=0 q \beta_{\mathrm{ij}} \mathrm{X}_{\mathrm{i}, \mathrm{t}-\mathrm{j}}^{\prime}+\varphi_{\mathrm{i}}+\varepsilon_{\mathrm{it}} \ldots \ldots \ldots[3]$

where $y_{i t}$ is the dependent variable, $X_{i t}^{\prime}$ is a $k \times 1$ vector that are allowed to be purely $i(0)$ or $i(1)$ or cointegrated, $\delta_{i j}$ is the coefficient of the lagged dependent variable called scalars, $\beta_{i j}$ are $k \times 1$ coefficient vectors, $\varphi_{i}$ is the unit-specific fixed effects. Number of cross-sections $i=1,2, \ldots, N$ and time $\mathrm{t}=1,2,3 \ldots, \mathrm{T}$. $\varepsilon_{\mathrm{it}}$ is the error term.

Equation 3 can be re-parametrized onto ARDL error correction specification as:

$\mathrm{y}_{\mathrm{it}}=\theta_{\mathrm{i}}\left[\mathrm{y}_{\mathrm{i}, t-1}-\lambda_{\mathrm{i}} \mathrm{X}_{\mathrm{t}, \mathrm{i}}\right]+j=1 p-1 \delta_{\mathrm{ij}} \Delta \mathrm{y}_{\mathrm{i}, \mathrm{t}-\mathrm{j}}+j=0 q-1 \beta_{\mathrm{ij}} \Delta \mathrm{X}_{\mathrm{i}, t-\mathrm{j}}+\varphi_{\mathrm{i}}+\varepsilon_{\mathrm{it}} \ldots \ldots \ldots[4]$

where $\theta_{\mathrm{i}}=$ group-specific speed of adjustment coefficient, $\lambda_{\mathrm{i}}$ is vector of long-run relationships, $\left[\mathrm{y}_{\mathrm{i},-1-1}-\lambda_{\mathrm{i}} \mathrm{X}_{\mathrm{t}, \mathrm{i}}\right]$ is error correction term or ECT, $\delta_{\mathrm{ij}}$ and $\beta_{\mathrm{ij}}$ are short-run dynamic coefficients.

\section{Result and Discussion \\ Descriptive Analysis}

Two measures of accounting performance of the sample banks used in the study are return on equity (ROE) and return on assets (ROA). Roe fluctuates from $37.75 \%$ to $1.45 \%$ with a mean value of $20.10 \%$. Similarly, ROA ranges from $0.16 \%$ to $4.01 \%$. ROE is more volatile than ROA as ROE is affected by ROA and leverage as well. The stock market performance measured by stock return and lagged stock return have almost the same fluctuation but the standard deviation is much higher showing that the stock market was more volatile during the study period. Risk performance measured by non-performing loans to total loan ratio and lag of risk-weighted exposure for credit risk shows a minimum fluctuation indicating that banks 
have managed their credit risk consistently. Loan growth and one-year lagged loan growth have a standard deviation of around $13 \%$ showing a moderate fluctuation.

[Insert Table 1 around here]

\section{Correlations Analysis}

Table 2 presents the Pearson's correlation coefficient between variables used in the study. There is a negative correlation between loan growth and accounting performance as the correlation of ROA and ROE with LG and $L_{\mathrm{t}-1}$ respectively are negative. However, the correlations with $\mathrm{LG}_{\mathrm{t}-1}$ are not significant at $5 \%$. The negative correlations show that increased loan growth results in higher risk and causes profitability to decrease. On the other hand, stock returns in the same year and one-year back are positively related to the loan growth, $L G$ and $L G_{t-1}$. This indicates that the stock price increases with the increase in loan growth. This also means that loan growth gives a positive signal to the market. Two variables taken to represent the risk performance show opposite results. NPL has negative and significant correlations with the loan growth but the risk-weighted exposure has a positive correlation. This indicates that when banks are more careful in lending and even if they loaned more, the rate of default does not increase. On the contrary, when loan volume increases, the weight of risky assets increases and total risk-weighted exposure also increases. The correlation coefficient between $L G$ and $L_{\mathrm{t}-1}$ is very low and insignificant indicating no problem of multicollinearity.

[Insert Table 2 around here]

\section{Unit Root Test}

Table 3 presents the result of the unit root test of individual variables using Levin et al. (2002). All variables except LNRWA are stationary at level and LNRWA is stationary at first difference. While calculating t-stats, individual intercept is assumed. Since none of the variables is I(2), the ARDL model can be applied for estimation.

[Insert Table 3 around here]

\section{Loan Growth and Profitability Performance}

The results presented in Table 4 show that there is no long-run impact of loan growth on the profitability of banks as the long-run coefficients of LG and $\mathrm{LG}_{\mathrm{t}-1}$ are insignificant at $5 \%$. However, in the short run, loan growth and profitability are cointegrated. Any deviation in ROA and ROA is corrected by loan growth as the coefficients of error correction term (ECT) are negative and significant. The deviation in $\mathrm{ROA}$ is corrected by loan growth at a speed of $36.59 \%$ each year and the deviation in ROE is corrected by loan growth at a speed of $22.56 \%$ each year. Since the coefficients of $\mathrm{D}(\mathrm{LG})$ and $\mathrm{D}\left(\mathrm{LG}_{\mathrm{t}-1}\right)$ are negative and only the coefficient of LG in ROA regression is significant at $5 \%$. This shows that loan growth in the same year and one year back cannot influence the profitability of a bank significantly. These results support Thiongo et al. (2016) but contradict Fahlenbrach et al. (2018) and Foos et al. (2010). 
[Insert Table 4 around here]

Looking at the coefficients of interest rate spread, there is no long-run association between loan growth and interest rate spread. However, the deviation in spread is corrected at a speed of $82.37 \%$ each year by loan growth in the short-run. The previous year's loan growth has no impact on this year's spread as the coefficient of $D\left(L_{t-1}\right)$ is insignificant. However, the coefficient of $D(L G)$ is positive and significant meaning that when loan growth increases, the spread also increases. This is the opposite of expectation as banks are aggressive in lending, they may work in low spread.

\section{Loan Growth and Stock Return}

There is no long-run association between loan growth and stock return of banks as the longrun coefficients of loan growth presented in panel A and panel B of Table 5 are not significant. Since the coefficient of ECT is significant at $5 \%$, the deviation in stock return is corrected by loan growth in the short-run. The result shows that the previous year's loan can predict this year's stock return. The positive and significant coefficient of $\mathrm{D}\left(\mathrm{LG}_{\mathrm{t}-1}\right)$ indicates that loan growth in the previous year results in increased stock return in this year. The result contradicts the findings of Niu (2016) and supports the findings of Pouvelle (2012).

[Insert Table 5 around here]

\section{Loan Growth and Credit Risk}

Table 6 presents the long-run and short-run regression results for the impact of loan growth on credit risk. Panel B shows that there is no long-run and short-run association between loan growth and credit risk as all the coefficients of loan growth on NPL are insignificant at $5 \%$. Similarly, the loan growth has no long-run influence on risk-weighted exposure for credit risk. In the short-run, however, loan growth has a positive and significant influence on riskweighted exposure. This indicates that when loan volume grows, the portion of risky assets increase and total risk-weighted assets also increase in the same year. However, the finding here contradicts the finding of Amador and Gomez (2013) and Chavan and Gambacorta (2016).

[Insert Table 6 around here]

\section{Conclusion}

This paper analyzed the information contents of loan growth of commercial banks in Nepal using the panel ARDL model. The effect of loans on three aspects of bank performance included in the study were profitability performance, stock return and credit risk. The analysis showed that there is no long-run influence of loan growth on any of the performance aspects included in the study. However, there is a short-run influence of loan growth on profitability and stock return. However, credit risk is not affected by the loan growth. In general, growth of loan volume can be interpreted as the banks are taking more risk and offering loans to the less creditworthy borrowers. But in the case of Nepal, loan growth is not the cause of taking 
risks and making loans to subprime customers, but it may be the result of increased deposits and sources of funds. This also means that banks in Nepal are not taking more credit risk to increase their loan volume. In other words, credit managers have no incentive to lend more to increase current profit.

The growth of loan volume has a positive and significant influence on bank profitability in the same year and one year ahead. While banks provide more loans, they earn more interest and profitability increases. Since non-performing loans are not increasing significantly with the increase in loan volume, there is no increment in bad debt. This certainly causes the net income to increase. Thus, increased lending results in increasing profitability. On the other hand, loan growth gives a positive signal to the stock market. The previous year's loan growth has a positive and significant impact on this year's stock return. As indicated earlier, increased loan volume does not result in increased bad debt, investors in the stock market also expect higher dividends because loan growth results in increased profit. Therefore, stockholders pay more for the stock of the bank, which has higher loan growth.

\section{Implications}

Since the credit risk of banks in Nepal does not increase with the increase in loan volume, the depositors and other outside lenders of banks need not be afraid of the increased loan volume of banks. The shareholders of a bank can expect higher return when loan grows faster because increased loan is associated with increased profitability. Similarly, the investors in the stock market can choose banks with higher loan growth to have a greater return from their stock investment because the previous year's loan is associated with increased stock return in this year. Further researchers may extend this study by increasing the sample banks and sampling period to check whether consistent results can be found or not. Similarly, loan growth may have an impact on other aspects of the bank such as liquidity, cost of fund etc. Further research can be made to include these aspects in the analysis of loan growth and its impact. 


\section{References}

Amador, J. S., Gómez-González, J. E., \& Pabón, A. M. (2013). Loan growth and bank risk: new evidence. Financial Markets and Portfolio Management, 27(4), 365-379.

Anundsen, A. K., Gerdrup, K., Hansen, F., \& Kragh $\square$ Sørensen, K. (2016). Bubbles and crises: The role of house prices and credit. Journal of Applied Econometrics, 31(7), 1291-1311.

Baker, D. (2008). The housing bubble and the financial crisis. Real-world Economics Review, $46(20), 73-81$.

Bordalo, P., Gennaioli, N., \& Shleifer, A. (2018). Diagnostic expectations and credit cycles. The Journal of Finance, 73(1), 199-227.

Chavan, P., \& Gambacorta, L. (2016). Bank lending and loan quality: The case of India. Bank for Internationa Settlement-working papers (Working paper No. 595). BIS.

Cyree, K. B., Mark, G. D., \& Winters, D. B. (2016). U.S. bank lending activities in the post-crisis world. The Journal of Financial Research, 39(4), 389-410.

Fahlenbrach, R., Prilmeier, R., \& Stulz, R. M. (2018). Why does fast loan growth predict poor performance for banks?. Review of Financial Studies, 31(3), 1014-1063.

Foos, D., Norden, L., \& Weber, M. (2010). Loan growth and riskiness of banks. Journal of Banking and Finance, 34(12), 2929-2940.

Glen, J., \& Mondragón-Velez, C. (2011). Business cycle effects on commercial bank loan portfolio performance in developing economies. Review of Development Finance, 1(2), 150-165.

Ibrahim, M. H. (2006). Stock price and bank loan dynamics in a developing country: The case of Malaysia. Journal of Applied Economics, 9(1), 71-89.

Jorda, O., Schularick, M., \& Taylor, A. M. (2013). When credit bites back. Journal of Money, Credit and Banking, 45(2), 3-28.

Khan, U., \& Ozel, N. B. (2016). Real activity forecasts using loan portfolio information. Journal of Accounting Research, 54(3), 895-937.

Kim, S. B., \& Moreno, R. (1994). Stock prices and bank lending behavior in Japan. Economic Review-Federal Reserve Bank of San Francisco, (1), 31-42

Levin, A., Lin, C. F., \& Chu, C. S. J. (2002). Unit root tests in panel data: asymptotic and finitesample properties. Journal of Econometrics, 108(1), 1-24.

Liu, C. C., Ryan, S. G., \& Wahlen, J. M. (1997). Differential valuation implications of loan loss provisions across banks and fiscal quarters. The Accounting Review, 72(1), 133-146.

Niu, J. (2016). Loan growth and bank valuations. The Quarterly Review of Economics and Finance, 61(3), 185-191.

Pouvelle, M. C. (2012). Bank credit, asset prices and financial stability: Evidence from French banks (Working paper No. 12-103). IMF. 
Rajan, R. G. (1994). Why bank credit policies fluctuate: A theory and some evidence. Quarterly Journal of Economics, 109(2), 399-441.

Rose, P. S., \& Hudgins, S. G. (2008). Bank management and financial services. Boston: McGrawHill.

Soedarmono, W., Sitorus, D., \& Tarazi, A. (2017). Abnormal loan growth, credit information sharing and systemic risk in Asian banks. Research in International Business and Finance, 42, 1208-1218.

Thiongo, P. K., Matata, K., \& Simiyu, A. (2016). Effect of loan portfolio growth on the financial performance of commercial banks in Kenya. Imperial Journal of Interdisciplinary Research, 2(11), 2113-2141.

Vogiazas, S., \& Alexiou, C. (2015). Banking performance and the business cycle: Empirical evidence from Greece. Global Business and Economics Review, 17(4), 345-359.

Zemel, M. (2018). The information content of loan growth in banks. Quarterly Journal of Finance, 8(2), 1-32.

Table 1

Descriptive statistics

\begin{tabular}{lrrrrrrrrr}
\hline & ROE & ROA & SPREAD & SR & SR $_{t-1}$ & NPL & LNRWA & LG & LG $_{t-1}$ \\
\hline Mean & 20.10 & 1.93 & 4.45 & 9.08 & 4.44 & 0.94 & 10.91 & 20.79 & 20.01 \\
Median & 19.08 & 1.92 & 4.47 & 0.06 & -11.80 & 0.67 & 10.91 & 18.26 & 17.32 \\
Maximum & 37.75 & 4.01 & 7.09 & 183.74 & 183.74 & 4.29 & 11.95 & 84.65 & 84.65 \\
Minimum & 1.45 & 0.16 & 2.70 & -67.10 & -67.10 & 0.01 & 9.74 & 3.83 & -1.50 \\
Std. Dev. & 6.90 & 0.66 & 0.72 & 53.89 & 55.51 & 0.89 & 0.52 & 12.96 & 13.39 \\
\hline
\end{tabular}

Note: $\mathrm{N}=64$.

Table 2

Pairwise correlation coefficients between variables

\begin{tabular}{|c|c|c|c|c|c|c|c|}
\hline Variables & $\mathrm{ROE}$ & $\mathrm{ROA}$ & SPREAD & SR & NPL LNRWA & LG & $\mathrm{LG}_{t-1}$ \\
\hline ROE & 1 & & & & & & \\
\hline ROA & $\begin{array}{c}0.6941 \\
(0.000)\end{array}$ & 1 & & & & & \\
\hline SPREAD & $\begin{array}{r}0.3785 \\
(0.002)\end{array}$ & $\begin{array}{c}0.3883 \\
(0.001)\end{array}$ & 1 & & & & \\
\hline SR & $\begin{array}{c}0.1806 \\
(0.153)\end{array}$ & $\begin{array}{c}-0.0174 \\
(0.891)\end{array}$ & $\begin{array}{l}0.1826 \\
(0.148)\end{array}$ & 1 & & & \\
\hline NPL & $\begin{array}{l}0.1778 \\
(0.160)\end{array}$ & $\begin{array}{l}0.1523 \\
(0.229)\end{array}$ & $\begin{array}{l}0.2642 \\
(0.034)\end{array}$ & $\begin{array}{c}0.1399 \\
(0.270)\end{array}$ & 1 & & \\
\hline
\end{tabular}




\begin{tabular}{lrrrrrrrrr} 
LNRWA & -0.1184 & 0.0665 & -0.0381 & -0.3116 & -0.3216 & 1 & & \\
& $(0.351)$ & $(0.601)$ & $(0.765)$ & $(0.012)$ & $(0.009)$ & & & \\
LG & -0.2881 & -0.2767 & -0.2552 & 0.1640 & -0.1784 & 0.0306 & 1 & \\
& $(0.021)$ & $(0.026)$ & $(0.041)$ & $(0.195)$ & $(0.158)$ & $(0.810)$ & & \\
\multirow{2}{*}{ LG $_{\mathrm{t}-1}$} & -0.0589 & -0.0627 & -0.0160 & 0.0650 & -0.2599 & 0.1793 & 0.0785 & 1 \\
& $(0.644)$ & $(0.625)$ & $(0.899)$ & $(0.609)$ & $(0.038)$ & $(0.156)$ & $(0.537)$ & \\
\hline
\end{tabular}

Note: $\mathrm{N}=64$. Coefficients in the table are Pearson's correlations and values in parentheses are $\mathrm{p}$-values.

Table 3

Result of unit root test (Levin, Lin $\mathcal{E}$ Chu t-stat)

\begin{tabular}{|c|c|c|c|c|c|}
\hline \multirow[b]{2}{*}{ Variables } & \multicolumn{2}{|c|}{ Level } & \multicolumn{2}{|c|}{$1^{\text {st }}$ Difference } & \multirow[b]{2}{*}{ Order of integration } \\
\hline & t-stat & p-value & t-stat & p-value & \\
\hline LG & -8.4080 & 0.0000 & & & $I(0)$ \\
\hline $\mathrm{LG}_{\mathrm{t}-1}$ & -7.4780 & 0.0000 & & & $I(0)$ \\
\hline LNRWA & 1.6735 & 0.9529 & -7.7802 & 0.0000 & $I(1)$ \\
\hline NPL & -10.177 & 0.0000 & & & $I(0)$ \\
\hline ROA & -6.6611 & 0.0000 & & & $I(0)$ \\
\hline ROE & -6.0042 & 0.0000 & & & $I(0)$ \\
\hline Spread & -6.8238 & 0.0000 & & & $I(0)$ \\
\hline SR & -6.2906 & 0.0000 & & & $I(0)$ \\
\hline
\end{tabular}

\section{Table 4}

Regression output of loan growth on profitability

\begin{tabular}{|c|c|c|c|c|c|}
\hline \multicolumn{3}{|c|}{ Long-run equation } & \multicolumn{3}{|c|}{ Short-run equation } \\
\hline Variable & Coefficient & Prob. & Variable & Coefficient & Prob. \\
\hline \multicolumn{6}{|c|}{ Panel A: dependent variable is ROA. ARDL $(1,1,1)$} \\
\hline LG & -0.011719 & 1.000 & ECT & -0.365924 & 0.0003 \\
\hline \multirow{3}{*}{$\mathrm{LG}_{\mathrm{t}-1}$} & 0.070313 & 1.000 & $\mathrm{D}(\mathrm{LG})$ & -0.046030 & 0.0001 \\
\hline & & & $\mathrm{D}\left(\mathrm{LG}_{\mathrm{t}-1}\right)$ & -0.011387 & 0.2822 \\
\hline & & & C & 0.396322 & 0.0009 \\
\hline
\end{tabular}

Panel B: dependent variable is ROE. ARDL $(1,1,1)$

$\begin{array}{llllll}\mathrm{LG} & 0.343750 & 1.000 & \mathrm{ECT} & -0.225680 & 0.0433 \\ \mathrm{LG}_{\mathrm{t}-1} & 0.632813 & 1.000 & \mathrm{D}(\mathrm{LG}) & -0.003674 & 0.9546 \\ & & & \mathrm{D}\left(\mathrm{LG}_{\mathrm{t}-1}\right) & -0.115517 & 0.0951 \\ & & \mathrm{C} & -1.181963 & 0.1878\end{array}$

Panel C: dependent variable is SPREAD. ARDL $(1,1,1)$ 


\begin{tabular}{lrrlrr}
$\mathrm{LG}$ & 0.076660 & 1.000 & $\mathrm{ECT}$ & -0.823746 & 0.0004 \\
$\mathrm{LG}_{\mathrm{t}-1}$ & -0.043457 & 1.000 & $\mathrm{D}(\mathrm{LG})$ & 0.027074 & 0.0026 \\
& & & $\mathrm{D}\left(\mathrm{LG}_{\mathrm{t}-1}\right)$ & -0.006447 & 0.6052 \\
& & $\mathrm{C}$ & 2.881947 & 0.0000 \\
\hline
\end{tabular}

Table 5

Regression output of loan growth on stock return

\begin{tabular}{|c|c|c|c|c|c|}
\hline & \multicolumn{2}{|c|}{ Long-run equation } & \multicolumn{3}{|c|}{ Short-run equation } \\
\hline Variable & Coefficient & Prob. & Variable & Coefficient & Prob. \\
\hline LG & 0.729944 & 1.0000 & ECT & -1.041199 & 0.0000 \\
\hline $\mathrm{LG}_{\mathrm{t}-1}$ & -2.656589 & 1.0000 & $\mathrm{D}(\mathrm{LG})$ & 1.051722 & 0.2076 \\
\hline & & & $\mathrm{D}\left(\mathrm{LG}_{\mathrm{t}-1}\right)$ & 2.894975 & 0.0000 \\
\hline & & & $C^{t-1 /}$ & 93.65476 & 0.0000 \\
\hline
\end{tabular}

Table 6

Regression output of loan growth on credit risk

\begin{tabular}{|c|c|c|c|c|c|}
\hline & \multicolumn{2}{|c|}{ Long-run equation } & \multicolumn{3}{|c|}{ Short-run equation } \\
\hline Variable & Coefficient & Prob. & Variable & Coefficient & Prob. \\
\hline \multicolumn{6}{|c|}{ Panel A: dependent variable is RWA. ARDL $(1,1,1)$} \\
\hline LG & 0.781250 & 1.0000 & ECT & -0.009185 & 0.0092 \\
\hline \multirow[t]{3}{*}{$\mathrm{LG}_{\mathrm{t}-1}$} & -0.062500 & 1.0000 & $\mathrm{D}(\mathrm{LG})$ & 0.010759 & 0.0065 \\
\hline & & & $\mathrm{D}\left(\mathrm{LG}_{\mathrm{t}-1}\right)$ & 8.51E-05 & 0.8997 \\
\hline & & & C & 0.152317 & 0.0000 \\
\hline
\end{tabular}

Panel B: dependent variable is NPL. ARDL $(1,1,1)$

\begin{tabular}{llllll}
$\mathrm{LG}$ & 0.035156 & 1.0000 & $\mathrm{ECT}$ & -0.089390 & 0.7144 \\
$\mathrm{LG}_{\mathrm{t}-1}$ & 0.011719 & 1.0000 & $\mathrm{D}(\mathrm{LG})$ & -0.016511 & 0.1498 \\
& & & $\mathrm{D}\left(\mathrm{LG}_{\mathrm{t}-1}\right)$ & -0.019417 & 0.2399 \\
& & & $\mathrm{C}$ & -0.388595 & 0.0484 \\
\hline
\end{tabular}

